Bülent Güçyetmez

Aylin Çimet Ayyıldız

\section{Bir Tedavi Yaklaşımının İstenmeyen Komplikasyonu: Ovaryen Hiperstimülasyon Sendromu (OHSS)}

\author{
The Complication of a Treatment Approach: Ovaryen \\ Hyperstimulation Syndrome (OHSS)
}

Geliș Tarihi/Received: 11.09.2013

Kabul Tarihi/Accepted: 13.09.2013

Türk Yoğun Bakım Derneği Dergisi, Galenos Yayınevi tarafından basılmıștır.

Journal of the Turkish Society of Intensive Care, published by Galenos Publishing. ISNN: 1300-5804

Bülent Güçyetmez (四), Aylin Çimet Ayyıldız International Hospital, Genel Yoğun Bakım Ünitesi, Istanbul, Türkiye

E-posta: drbulentgucyetmez@yahoo.com Tel.: +90 2124684144
ÖZET Ovaryen Hiperstimülasyon Sendromu (OHSS); ovülasyon indüksiyonu sonrasında masif ovaryen büyüme, multipl ovaryen kistler, aşııı steroid hormon salınımı, kapiller geçirgenlik artışı, elektrolit imbalansı ve protein kaybı ile karakterize bir klinik tablodur. Klinik ve laboratuar bulgular göz önüne alındığında OHSS infeksiyöz olmayan bir SIRS tablosudur. OHSS'de spesifik bir tedavi yöntemi yoktur. Komplikasyonların önlenmesi ve tedavi edilmesi önceliklidir. OHSS'nin SIRS tablosu olarak kabul edilmesi ve tedavi yaklaşımlarının buna göre planlanması yoğun bakım gereksinimini önleyebilir.

Anahtar Kelimeler: Ovaryen Hiperstimülasyon Sendromu, OHSS, SIRS
SUMMARY Ovaryen Hyperstimulation Syndrome (OHSS) is a clinical state which is characterized with ovarian enlargement, multiple ovarian cysts, increased steroid release, increased capillary permeability, electrolyte disorder and reduced protein post ovulation induction. OHSS is a non-infectious SIRS according to the clinical and laboratory findings. There is no specific treatment for OHSS. Avoiding and treating complications are our priority. The ICU requirement can be reduced by taking OHSS as a SIRS and planning the treatment accordingly.

Key Words: Ovarian Hyperstimulation Syndrome, OHSS, SIRS 


\section{Ovaryen Hiperstimülasyon Sendromu}

Farmakolojik ovaryen stimülasyon son yıllarda infertilite alanında geniş kullanım alanı bulan iyi planlanmış terapötik bir prosedürdür (1). Bu tedavi yöntemi in vitro fertilizasyonun (IVF) başlangııından bu yana altın standart olarak kullanılmaktadır. 1930'larda tanımlanan Ovaryen Hiperstimülasyon Sendromu (OHSS) ise; ovülasyon indüksiyonu sırasında veya nadiren doğal siklusta da gelişebilen, masif ovaryen büyüme ve multipl ovaryen kistler ile karakterize, aşırı steroid hormon ve kapiller geçirgenlik artışı sonucu elektrolit bozukluğu ve protein kaybı ile seyreden bir sendromdur $(2,3)$. Son yıllarda insidansı giderek artan OHSS gelişiminden (\%1-23), ovulasyon indüksiyonu için kullanılan klomifen sitrat (CC), human menopozal gonodotropin (hMG), folikül stimülan hormon $(F S H)$, gonodotropin salgılatıcl hormon $(G n R H)$, $\mathrm{GnRH}$ analogları, human koriyonik gonadotropin (hCG) gibi ajanlar sorumlu tutulmaktadır $(2,4)$.

OHSS tanılı hastalarda yoğun bakım gereksinimi; böbrek yetersizliği, pulmoner komplikasyonlar (plevral efüzyon, ARDS, pulmoner ödem, pnömoni vb.) ve tromboembolik olaylar (pulmoner emboli, serebral emboli vb.) sonucu gelişir. Yoğun bakımın OHSS tanılı hastaya bakış açısı 3 başlık altında toplanabilir;

a. Yoğun bakım gereksinimini önleyici yaklaşımlar

b. Yoğun bakım zamanlaması (ne zaman yoğun bakım?)

c. Yoğun bakımda organ destek tedavileri

Bu yazının amacı OHSS tanılı hastalarda yoğun bakım gereksinimini ortadan kaldıracak yaklaşımları ortaya koymaktır. Bu nedenle yoğun bakım uzmanı gözüyle OHSS tanılı hastaya bakabilmek için OHSS patofizyolojisinin anlaşılması önemlidir.

\section{OHSS ve Sistemik İnflamatuar Yanıt Sendromu (SIRS) Illişkisi}

SIRS; 1992 yilında "The American College of Chest Physicians and Society of Critical Care Medicine" (ACCP/ SCCM) konferansında tanımlanmıştır. Akut pankreatit, yanık, cerrahi ve travma gibi infeksiyöz olmayan nedenlerle oluşan ve aşağıdaki kriterlerden en az ikisinin varlığı ile tanı konulan klinik bir tablodur (5) (Tablo 1).

Immün sistemin en önemli komponenti olan sitokinler hücreler arası iletişimi sağlarlar. SIRS'te ciddi bir sitokin fırtınası oluşur. Hücre membranında farklı uyaranlara spesifik olan Tool-like reseptörler; (TLR)(6,7) nükleer faktör (NF)-кB aktivasyonu ile tümör nekrotizan faktör (TNF- $\alpha$ ), interlökin-1 (IL-1), interlökin-6 (IL-6), interlökin-8 (IL-8) gibi proinflamatuar sitokinlerin aşırı miktarlarda üretilmesine neden olur (810) (Șekil 1). Bașlangıçta doku hasarını sınırlandıııcı lokal koagülasyon, aşırı proinflamatuar sitokin salınımı ile patolojik inflamatuar bir hastalığa dönüşür (11). Kontrol edilemeyen immün yanıt infeksiyöz olmayan SIRS'e neden olarak $(12,13)$. damar geçirgenliğinde artış, distribütif şok, hipoperfüzyon ve doku oksijenasyonunun bozulması ile sonuçlanır.
OHSS patofizyolojisinde ise östradiol, LH, hCG, reninanjiyotensin sistemi, vasküler endotelyal büyüme faktörü (VEGF) ve inflamatuar mediatörler sorumlu tutulmuştur (14-17). OHSS hastalarında FSH-reseptör mutasyonu olduğu gösterilmiştir (18). Bununla birlikte östradiol düzeyi yükselmeden OHSS gelişen hastalar rapor edilmiştir (19). Ayrıca OHSS'de akut dönemde plazma IL-1, IL-6 ve TNF- $\alpha$ konsantrasyonlarının yükselerek (20) vasküler geçirgenlik artışı, hemokonsantrasyon ve hipoperfüzyona neden olduğu gösterilmiştir (21). OHSS'de klinik (taşipne, dispne, hipotansiyon, batın distansiyonu, plörezi, perikard efüzyonu) ve laboratuvar (lökositoz, Ht yüksekliği, hipokarbi, plazma sitokin artışı) (22) bulgular göz önüne alındığında infeksiyöz olmayan bir SIRS tablosunun yaşandığı veya yaşanacağı bilinmelidir. SIRS tablosunu tetikleyen neden ne olursa olsun proinflamatuar sitokinlerin salınımı ve sitokin fırtınası yoğun bakım desteğini gerektirebilecek komplikasyonlar oluşturmaktadır.

OHSS'de, inflamatuar mediatörlerin neden olduğu kapiller geçirgenlik artışına (capillary leak syndrome) bağlı bir çeşit şok kliniği gözlenir ve intravasküler sıvının interstisyel alana kaçışı hipovolemi ile sonuçlanır. OHSS hastalarında masif sıvı şiftinin en önemli patoloji olduğu ilk kez Engel ve arkadaşları tarafından gösterilmiştir (23). OHSS'de görülen klinik ve laboratuvar bulguları, sitokinlerin neden olduğu damar geçirgenlik artışına bağlı üçüncü boşluklara sıvı kaçışı sonucu oluşur. (asit, plevral efüzyon, perikardiyal effüzyon vb.) Bu nedenle OHSS sınıflaması klinik bulgular ve ovaryen değişikliklerle yapılmaktadır (Tablo 2) $(24,25)$.

Tablo 1. SIRS kriterleri

Ateş $>380$ C veya $<360 \mathrm{C}$
Kalp Hızı $>90 / \mathrm{dk}$
Solunum sayıs $>20 / \mathrm{dk}$ veya $\mathrm{PaCO}^{2}<32 \mathrm{mmHg}$
Lökosit sayısı $>1200 / \mathrm{mm}^{3},<4000 / \mathrm{mm}^{3}$ veya
$>\% 10$
immatür

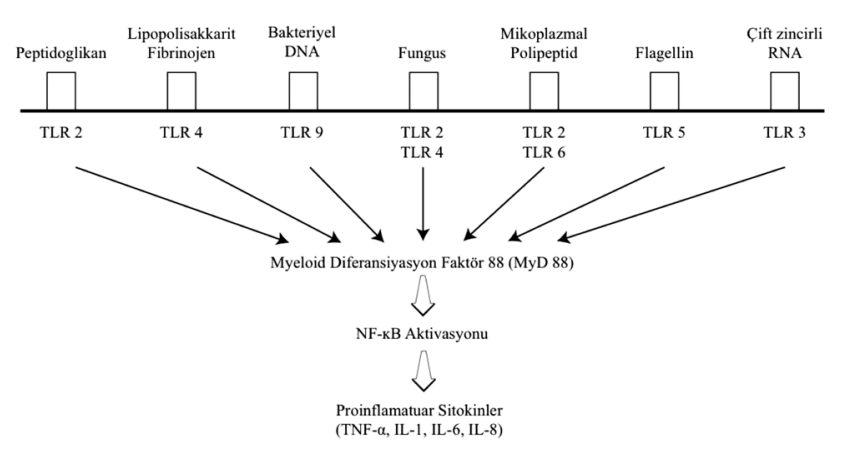

Şekil 1. Proinflamatuar sitokin üremi 
OHSS'de spesifik bir tedavi yöntemi yoktur. Kist rüptürü sonucu intraperitoneal kanama gelişmesi veya over torsiyonu olması durumunda over korunarak cerrahi müdahale yapılabilir. Gebelikle birliktelik gösteren OHSS'de terapötik abortus hayat kurtarıcı olabilmektedir. Bu nedenle komplikasyonların tedavi edilmesi ve organ fonksiyonlarını koruyucu tedavi yaklaşımlarının uygulanması önceliklidir.

\section{Yoğun Bakım Gereksinimini Önleyici Yaklașımlar}

Yoğun bakım gereksinimine kadar gidebilecek sürecin doğru yönetilmesi morbidite ile doğrudan ilişkilidir. OHSS sınıflamasına göre ağır OHSS'de (evre 4 ve evre 5) yoğun bakım gereksinimi doğmaktadır. Hastanın hospitalizasyonu ile başlayan bu süreçte ağır OHSS tablosunun oluşumunun engellenebilmesi aşağıda belirtilen sistem fonksiyonlarının doğru zamanda ve doğru şekilde desteklenebilmesi ile mümkün olabilir.

\section{A) Renal Koruma}

OHSS hastalarında oluşan kapiller geçirgenlik artışı, görece hipovolemiye neden olarak böbrek perfüzyonunu bozar. Intravasküler hipovolemiye bağlı oluşan hemokonsantrasyon ve hiperkoagülabilite tubullerde mikrotrombüslere neden olarak akut renal yetmezlik ile sonuçlanabilir (26). Ayrıca intraabdominal basıncı artıran asit oluşumu da renal perfüzyonu bozarak akut renal yetmezliğe neden olabilir. Bu nedenle OHSS'de renal koruma üç başlık altında toplanabilir;

\section{a) Renal fonksiyonun takip parametreleri;}

Akut böbrek yetmezliği 2004 yılında Akut Diyaliz Kalite Girişim Grubu (Acute Dialysis Quality Initiative Group) tarafından yeniden tanımlanmış ve sınıflandııımıştır (27). RIFLE sınıflaması olarak adlandırılan bu sınıflama içerisinde akut böbrek yetmezliği yerine "akut böbrek hasarı (ABH)" terimi kullanılmıştır. Renal hasarın erken dönemde saptanması için son yıllarda RIFLE kriterleri kullanılmaktadır (Tablo 3).

SIRS ve sepsis arasındaki fark kanıtlanmış infeksiyon varlığı ve organ yetmezliğidir. Sepsiste yeni yaklaşım; infeksiyon şüphesi varlığında SIRS kriterleri ile birlikte organ yetersizliğinin olmasını ciddi sepsis olarak kabul edilmektedir.

\section{Tablo 2. OHSS sınfflaması}

Hafif OHSS

$\begin{array}{ll}\text { Grade I: } & \text { Abdominal gerginlik ve rahatsıllik } \\ \text { Grade II: } & \text { Bulant//kusma/daire ve } 5-12 \mathrm{~cm} \text { overler }\end{array}$

Orta OHSS

Grade III: Ultrasonografik olarak asit tespiti

Ağır OHSS

Grade IV: $\quad$ Klinik asit, plevral effüzyon ve solunum zorluğu

Grade V: Kan volümü değişikliği, hemokansantrasyon ve viskosite artışı, koagülasyon bozukluğu, böbrek etmezliği ve oligüri
SIRS varlığında inflamatuar mediatörlerin renal hasar oluşturduğuna dair çalışmalar vardır (28). Renal hasarın erken tanınması için retinol bağlayıcı protein (RBP), sistatin C, böbrek hasar molekülü (KIM-1) gibi üriner belirteçler kullanılabilir (29).

b) Renal perfüzyonun korunması ve sıvi tedavisi;

Renal perfüzyonun korunmasında en basit ve etkin yöntemler; sıvı tedavisi ve optimum kan basıncının sağlanmasıdır.

- Hedefe yönelik erken sıvı tedavisi;

OHSS hastalarında ortalama arter basıncı (OAB) $65 \mathrm{mmHg}$ altında ve hematokrit $(\mathrm{Ht})$ değeri \%45 üzerinde ise hedefe yönelik erken sıvı tedavisine başlanmalıdır. Septik şokta ilk 6 saat içinde yapılan hedefe yönelik erken sıvı tedavisi mortaliteyi azaltmaktadır $(30,31)$. OHSS tanılı hastalarda hedefe yönelik erken sIvı tedavisinde ilk 3 saat içinde $1000 \mathrm{ml}$ kristalloid veya 300-500 ml kolloid sıvı replasmanı yapılmalıdır. Hipotansiyon ve hemokonsantrasyon düzeltilemediyse sIVI tedavisi tekrarlanabilir. Hipotansiyon ve hemokonsantrasyonun düzelmesi durumunda idame tedavisi planlanmalıdır. Altı saat sonunda hedef değerlere ulaşılamıyorsa hasta yoğun bakım uzmanı tarafından değerlendirilmelidir (Şekil 2).

- Idame sıvı tedavisi;

Idame sıvı tedavisi optimum intravasküler volümü sağlamayı ve kapiller kaçışı engellemeyi amaçlar. Bu nedenle OHSS tanılı hastalar saatlik bazal sıvı intiyaçları kadar kristalloid

Tablo 3. RIFLE kriterleri

\begin{tabular}{lll}
\hline & Serum kreatinin kriteri & idrar miktarı kriteri \\
\hline R (Risk) & Kretinin x 1,5 & 6 saattir, $<0,5 \mathrm{ml} / \mathrm{kg} / \mathrm{sa}$ \\
& & 12 saattir, $<0,5 \mathrm{ml} /$ \\
$\mathrm{I}$ (Injury; hasar) & Kretinin $\times 2$ & $\mathrm{~kg} / \mathrm{sa}$ \\
$\mathrm{F}$ (Failure; yeter- & & 24 saattir, $<0,3 \mathrm{ml} / \mathrm{kg} /$ \\
sizlik) & Kretinin $\times 3$ & sa veya 12 saattir anuri \\
L (Loss; kayıp) & 4 haftadır kalıı böbrek hastalığı olması \\
$\begin{array}{l}\text { E (End-stage renal } \\
\text { disase son dönem } \\
\text { böbrek hastalığı) }\end{array}$ & 3 aydan fazla böbrek hastalığının olması \\
\hline
\end{tabular}

Tablo 4. 2012 Berlin ARDS kriterleri

*Solunum yetersizliğinin sebeb olabilecek klinik oladan sonraki 7 gün içinde gelişmesi

*Radyolojik tetkiklerde effüzyon ve atelaktazi ve nodül ile açılanamayacak bilateral opsite varlığı

*Kardiojenik pulmoner ödem ve akciğer volüm yükü ile açılanmayan solunu yetersizliği

*PEEP $\geq \mathrm{CmH}_{2} \mathrm{O}$ iken

Hafif ARDS : $200<\mathrm{PaO}_{2} / \mathrm{FiO}_{2} \geq 300$

Orta ARDS : $100<\mathrm{PaO}_{2} / \mathrm{FiO}_{2} \geq 200$

Ciddi ARDS : $<\mathrm{PaO}_{2} / \mathrm{FiO}_{2} \geq 100$ 
sıvı almalıdır (1,5 ml/kg/saat). Kristalloid sıvının seçiminde sıvının dekstroz içeren sıvılar gibi hipotonik olmaması ve elektrolit dengesinin korunması önemlidir. Bu grup hastada $\mathrm{Ht}$ değeri ve ekokardiyografi bulguları intravasküler alanın doluluğu hakkında fikir verebilir fakat hastada kullanılacak sIVI tipinin belirlenmesinde ve ne zaman diüretik yapılması gerektiğinin saptanmasında tek başına yeterli olmaz. Bu durumda $\mathrm{Ht}$ değeri ile kolloid onkotik basıncın (KOB) birlikte değerlendirilmesi önemli avantajlar sağlayabilir. Intravasküler alanda büyük molekül ağırlığına sahip protein yapılı maddeler onkotik basınç yaratarak intravasküler alandaki sıvının ekstravasküler alana kaçışını engeller.(32) KOB olarak ifade edilen bu basınç hastalarda kullanılacak SIVI tipinin belirlenmesinde önemli bir belirteç olarak kullanılabilir. Dengeli elektrolit içeren ve hipotonik olmayan kristalloid sIVI seçimi, Hct ve KOB değerlerine göre kristalloid/kolloid sIVI kombinasyonlarının uygulanması ve gerektiği zaman diüretik ile destek sağlanması, hem intravasküler alanda yeter miktarda volüm oluşturulmasını sağlar hem de kapiller kaçışı önler. Seçilebilecek kolloid sivilar Hydroxyethyl starch (HES), jel ve dekstranlar gibi yapay $(20 \mathrm{ml} / \mathrm{kg} / \mathrm{gün})$ veya albümin gibi doğal (0,5-1 g/kg/gün) kolloidler olabilir (Şekil 2).

Albümin intravasküler onkotik basıncın \%80'inden sorumludur. In vivo yarılanma ömrü 18-21 gündür ve bir gram albümin yaklaşık $18 \mathrm{ml}$ sıvı tutma kapasitesine sahiptir (33). OHSS tanılı hastalarda tedavinin başlangıcından itibaren albümin kullanılabilir fakat allerjik reaksiyonlara neden olabileceği unutulmamalıdır. Bu nedenle son yıllarda albümin intravenöz bolus uygulamalar yerine 2-4 g/saat infüzyon olarak uygulanmaktadır.

HES solüsyonları amilopektinden formüle edilmiştir ve glukozun lineer bir polimeridir. Molekül ağırlığı, substitisyon oranına göre tanımlanan HES solüsyonları büyük molekül ağırlıklı ve büyük substitüsyon oranlı (450/0.6) olup, plazma

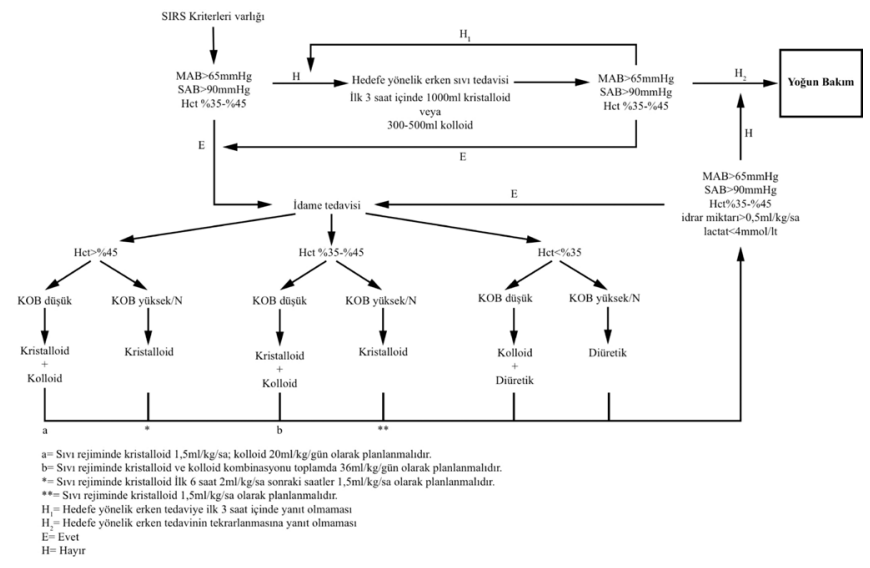

Şekil 2. OHSS'de SIVı tedavi algoritması (septik şok sIVı tedavisinden esinlenerek yazarlar tarafından oluşturulmuştur) genişletici özellikleri 24-36 saat sürmektedir. Yeni nesil HES solüsyonları ise küçük molekül ağırlıklı ve küçük substitüsyon katsayılıdır (130/0.4) ve bu solüsyonların plazma genişletici özellikleri 4-6 saat kadardır. Yüksek ve orta molekül ağırlıklı HES solüsyonlarının faktör VIII ve von Willebrand faktörü düzeyini düşürerek koagülopatilere yol açtığı gösterilmiştir. Düşük molekül ağırıkı HES solüsyonlarında koagülopati daha az görülür. Orta ve büyük molekül ağırlıklı HES solüsyonlarının şiddetli sepsis veya septik şokta kullanımasının renal hasarı arttırdığı öne sürülmüştür. Erişkin cerrahi hastalar için intravenöz SIVI tedavisi rehberi (Guidelines on Intravenous Fluid Therapy for Adult Surgical Patients) molekül ağırlığı 200 kDa'dan küçük HES solüsyonlarını kritik hastalarda önermektedir. Ancak daha küçük molekül ağırlıkı (130 kDa'dan küçük) HES solüsyonları geniş sayıda olguda araştırılmamıştır $(34,35)$. Idame tedavisine rağmen $O A B$ $<65 \mathrm{mmHg}, \mathrm{Ht}>\% 45$, idrar miktarı $<0,5 \mathrm{ml} / \mathrm{kg} / \mathrm{saat}$, (Rifle kriterleri / Risk) laktat $>4$ mmol/lt olması durumunda hastanın yoğun bakım uzmanı tarafından değerlendirilmesi uygun olur (Şekil 1).

\section{c) Abdominal basınç takibi ve kontrolü;}

Hipovolemi, travma, yanık ve septik şokta organ perfüzyonunu ve hemodinamik stabiliteyi korumak amacı ile agresif sıvı tedavileri uygulanmaktadır. Son yıllarda yapılan bazı klinik araştırmalar agresif sıvı tedavisi stratejilerinin morbidite ve mortaliteyi arttırdığını göstermiştir (31). Kapiller geçirgenlik artışı varlığında yapılan agresif sıvı tedavisi pulmoner ödem gelişmesine ve intraabdominal basınç artışına bağlı abdominal kompartman sendromuna (AKS) neden olabilir. AKS; intraabdominal basıncın $20 \mathrm{mmHg}$ üzerinde olması olarak tanımlanır ve organ disfonksiyonu nedenidir (36). Intraabdominal basınç artışı aşağıdaki gibi derecelendirilmiştir.

- Evre I 12-15 mm Hg

- Evre II 16-20 mm Hg

- Evre III 21-25 mm Hg

- Evre IV $>25 \mathrm{mmHg}$

OHSS tanılı hastalar asit oluşumu nedeniyle AKS'ye adaydır. Travma, yanık ve sepsiste kolloid sıvıların ve düşük volümlü hipertonik sodyum kullanımının AKS gelişimini azalttığına dair çalışmalar mevcuttur $(36,37)$. Bu nedenle OHSS tanılı hastalarda doğru sıvı tedavisi ile birlikte evre II intraabdominal basınç artışı saptandığında parasentez yapılması renal disfonksiyonu önlemede oldukça önemlidir.

\section{B) Pulmoner Koruma}

OHSS'de artmış kapiller geçirgenlik nedeniyle perikardiyal, peritoneal, plevral alanlara ve alveollere sıvı geçişi görülebilir. Pulmoner ödem, ARDS, masif pulmoner efüzyon, pulmoner emboli gibi komplikasyonlar solunumsal destek ve yoğun bakım takibi gerektirebilir. Geriye dönük olarak yapılan bir çalışmada Ağır OHSS hastalarında dispne (\%92), lober pnömoni (\%2), ARDS (\%4) ve pulmoner emboli (\%2) gibi pulmoner komplikasyonlar geliştiği bildirilmiş̧ir (38). 
- Plevral Effüzyon;

Ağır OHSS hastalarının \%10 ile \%29 arasında plevral efüzyon görülebilmektedir $(38,39)$. Klinik olarak dispne, solunum seslerinde azalma; akciğer grafisinde ise efüzyon ve komşuluğunda atelektaziler görülebilmektedir. Plevral efüzyonu olan hastalarda klinik olarak taşipne, dispne varlığında ve lateral dekübit pozisyonunda çekilen akciğer grafisinde $10 \mathrm{~mm}$ üzerinde efüzyon sınırı varsa veya radyolojik bulgulara göre $1500 \mathrm{ml}$ üzerinde sıvı birikimi olduğu öngörülüyorsa efüzyonun boşaltılması önerilmektedir. Plevral efüzyon boşaltılması sırasında oluşabilecek pnömotoraks, hemotoraks, organ laserasyonu ve özellikle damar geçirgenliği bozulmuş olan OHSS hastalarında reekspansiyon pulmoner ödem gibi komplikasyonlar göz önünde bulundurulmalıdır.(40)

Plevral effüzyonun boşaltılmasından sonra solunum sıkıntısı devam eden, görüntülemelerde atelektazik alan gözlenen hastalarda solunum fizyoterapisi başlanmalı, gerekirse katta veya yoğun bakım şartlarında non-invazif mekanik ventilasyon (NIMV) uygulanmalıdır. Bu nedenle hastalar yoğun bakım uzmanı ile birlikte değerlendirilmelidir.

- Akut respiratuar distres sendromu (ARDS);

Kardiyojenik olmayan özellikte, akut başlangıçlı, inflamatuar diffüz pulmoner infiltrasyon ve bozulmuş oksijenizasyonla karakterize akut solunum yetersizliği sendromu olan akut respiratuar distres sendromu (ARDS) ilk olarak 1967 yllında isimlendirilmiştir. Takip eden yıllarda bu tanımlamada birçok değişiklik olmuş, 1994 yılında Amerikan-Avrupa uzlaşı konferansı (AECC) raporu ile klinik kullanımı daha kolay tanı kriterleri belirlenmiştir. 2012 yılında AECC çalışması ile "ARDS Berlin Tanımlaması" oluşturulmuştur (Tablo 4) (41).

ARDS OHSS'nin nadir görülen komplikasyonlarındandır. Patofizyoloji tam olarak bilinmemekle birlikte otopsi bulgularına göre salınan VEGF ve sitokinlerin neden olabileceği düşünülmektedir. Artmış progesteronun kapiller kaçak sendromuna neden olarak pulmoner ödem ve ARDS'ye neden olduğu düşünülmektedir.

OHSS tanılı hastalar olası solunum sıkıntısı açısından izlenmeli, dispne, taşipne, oksijen intiyacında artma olması halinde yoğun bakım uzmanı ile konsülte edilmelidir. Kan gazı analizi ve radyolojik tetkiklere göre ARDS kriterlerinin hastada oluşması halinde yoğun bakım uzmanı ile birlikte tedavileri düzenlenmeli, gerekirse serviste veya yoğun bakım şartlarında NIMV desteğine başlanmalıdır. Ciddi ARDS hastaları ve NIMV uygulanmasına rağmen klinik iyileşme sağlanamayan hastaların takipleri yoğun bakım ünitesinde yapılmalıdır.

\section{C) Tromboemboli Proflaksisi}

Gebelik için kullanılan yöntemler sonucu oluşan OHSS'ye bağlı tromboemboli literatürde ilk kez 1964 ylında Sterwart ve ark. tarafından tanımlanmış ve hastaların \% 75 'inde ven trombozu, \%25'inde arter trombozu olduğu gösterilmiştir.(42)
OHSS'de tromboemboli nedenleri aşağıda sıralanmıştır;

1- Hemokonsantrasyon

Ovaryen hiperstimülasyonda üretilen vazoaktif maddeler; kapiller geçirgenlik artışı ve üçüncü boşluklara intravasküler sıvının kaçmasıyla hemokonsantrasyona yol açmaktadır.

2- Venöz staz

Büyüyen overler ve gelişen asit, özellikle şiddetli OHSS'li hastalarda alt ekstremite venöz drenajını yavaşlatmaktadır.

3- Östrojenin koagülasyon sistemi üzerindeki etkisi

Yüksek serum E2 düzeyi fibrinojen sentezini arttııı ve AT III düzeyini düşürür. VWF, Faktör VII, V, Fibrinojende azalma, aktive protein $\mathrm{C}$ rezistansında, protein $\mathrm{C}, \mathrm{S}$ aktivitesinde azalma olmaktadır (43-49).

Tromboemboli açışından risk taşıyan ve yeterli mobilizasyon sağlanamayan OHSS hastalarında kontrendikasyon yoksa erken dönemde profilaktik intermittan pnömotik kompresyon ve antikoagülan tedavi başlanmalıdır.

Yoğun bakım zamanlaması (ne zaman yoğun bakım?)

Bir hastada yoğun bakım desteğinin ne zaman başlaması gerektiğinin kararı önemlidir. Yoğun bakım uzmanları bu kararı verirken hastanın daha önce sahip olduğu hastalıkları, hastanede yatmasını gerektiren yeni hastalığı ve bu hastalığın olası sonuçları ile birlikte tüm organ fonksiyonlarını bir arada değerlendirir. Öncelikle hastaya ait sorunların yoğun bakıma alınmadan çözülebilmesi için çaba harcanır. Yoğun bakım yatışı beraberinde maliyet artışı, morbidite ve mortaliteyi getirmektedir. Bununla birlikte yoğun bakım takibi için organ yetersizliği oluşumu beklenilmemelidir. Uygulanan tedavilere rağmen istenen laboratuvar ve klinik hedeflere ulaşılamıyorsa, ileri monitörizasyon, vital bulguların yakın takibi ve organ fonksiyonlarının desteklenmesi için hastaların yoğun bakıma alınması gerekir.

Infeksiyöz olmayan SIRS olarak kabul edilen OHSS'de sIVI tedavisine rağmen hemodinamik instabilite ve renal hasara ait laboratuvar bulgularının devam etmesi; intraabdominal basınç artışı, pulmoner ödem veya plevral efüzyon nedeniyle solunum yetmezliği bulgularının oluşması durumunda hastanın takip ve tedavileri yoğun bakımda yapılmalıdır.

\section{Yoğun Bakımda Organ Destek Tedavileri}

Yoğun bakım üniteleri, hastaların yoğun bakım uzmanları tarafından takip edildiği ve çok disiplinli yaklaşımın gerekli olduğu alanlardır. Yoğun bakımın genel takip ve tedavi prensipleri OHSS tanılı hastalar için de geçerlidir. Yoğun bakımda takip edilen hastalarda doku oksijenasyonu ve organ perfüzyonunu sağlamak amaçlanır. Bu nedenle yapılan invazif monitörizasyonlarla (santral venöz kateterizasyon, invazif arter monitörizasyonu vb.) doku oksijenasyonu ve perfüzyonunun göstergeleri (SAB/DAB/OAB, ekokardiyografi, santral venöz basınç, $\mathrm{PCWP}, \mathrm{pH}, \mathrm{PaO}_{2}, \mathrm{PaCO}_{2}, \mathrm{SvO}_{2}$, laktat vb.) yorumlanır ve tedavi planı hazırlanır. Bu tedavi planının içinde sıvı tedavisi, solunum desteği (non invazif ve invazif mekanik ventilasyon), 
renal replasman tedavileri (hemodiafiltrasyon, hemodiyaliz), vazopressör ve inotropik ilaç destekleri, antibiyoterapi, destek tedavileri (kalori, vitamin, eser element vb.) tanıya özel girişim (torasentez, parasentez vb.) ve medikasyonlar (IVIG, hidrokortizon vb.) yer alır.

\section{Önemli Mesajlar;}

*OHSS; infeksiyöz olmayan SIRS tablosudur.

* Organ perfüzyonunu sağlayacak doğru sıvı rejimi uygulamaları ve koruyucu destek tedavileri yoğun bakım gereksinimini ortadan kaldırabilir.

* Istenen hedeflere ulaşlamaması durumunda yoğun bakım desteği sağlanmalı ve septik hasta ile karşı karşıya olunduğu unutulmamalıdır.

\section{Çıkar Çatışması}

Yazarlar herhangi bir çıkar çatışması bildirmemişlerdir.

\section{Kaynaklar}

1. Man A, Schwarz Y, Greif J. Pleural effusion as a presenting semptom of ovarian hyperstimulation syndrome. Eur Respir J 1997;10:2425-26.

2. Tan SL, Balen A, El-Hussein E, Campbell $\mathrm{S}$, Jacobs HS. The administration of glucocorticoids for the prevention of ovarian hyperstimulation syndrome in vitro fertilization: a prospective randomized study. Fertil Steril 1992;2:378-83.

3. Tsirigotis M, Craft I. Ovarian hyperstimulation ayndrome (OHSS): how much do we really know about it? Eur J Obst Gyn and Repro Biol 1994;55:151-5

4. Sueldo CE. Transient liver function test abnormalities in OHSS. Fertil Steril 1988;50:995-6.

5. Bone RC, Balk RA, Cerra FB, Dellinger $R P$, Fein AM, Knaus WA, et al. Definitions for sepsis and organ failure and guidelines for the use of innovative therapies in sepsis. ACCP/SCCM Consensus Conference Committee, American College of Chest Physicians/ Society of Critical Care Medicine. Chest 1992;101:1644-55.

6. Medzhitov R. Toll-like receptors and innate immunity. Nat Rev Immunol 2001;1:135-45

7. Takeda K, Kaisho T, Akira S. Tolllike receptors. Annu Rev Immunol 2003;21:335-76.

8. Suzuki N, Suzuki S, Duncan GS, Millar DG, Wada T, Mirtsos C, et al. Severe impairment of interleukin-1 and Toll-like receptor signaling in mice lacking IRAK-4. Nature 2002;416:750-56.

9. Zhang FX, Kirschning CJ, Mancinelli R, $X u X P$, Jin $Y$, Faure $E$, et al. Bacterial lipopolysaccharide activates nuclear factor- B through interleukin-1 signaling mediators in cultured human dermal endothelial cells and mononuclear phagocytes. J Biol Chem 1999;274:76114.
10. Lomaga MA, Yeh WC, Sarosi I, Duncan GS, Furlonger $\mathrm{C}$, Ho A, et al. TRAF6 deficiency results in osteopetrosis and defective interleukin-1, CD40, and LPS signaling. Genes Dev 1999;13:1015-24. 40 Lee J, Mira-Arbibe L, Ulevitch RJ

11. Ulloa L, Tracey KJ. The 'cytokine profile': a code for sepsis. Trends Mol Med 2005;11:56-63.

12. Ferrara JL. Cytokine dysregulation as a mechanism of graft versus host disease. Curr Opin Immunol 1993;5:794-99.

13. Makhija R, Kingsnorth AN. Cytokine storm in acute pancreatitis. J Hepatobiliary Pancreat Surg 2002;9:401-10.

14. Asch RH, Li HP, Balmaceda JP, Weckstein LN, Stone SC. Severe ovarian hyperstimulation syndrome in assited reproductive technology: definition of high risk groups. Hum. Reprod 1991;6:1395-9.

15. Soares SR, Gomez R, Simon C, GarciaVelasco JA, Pellicer A. Targeting the vascular endothelial growth factor system to prevent ovarian hyperstimulation syndrome. Hum. Reprod. Updat 2008;14:321-33.

16. Fernandez LA, Tarlatzis BC, Rzasa PJ, Caride VJ, Laufer N, Negro-Vilar AF, et all. Renin-like activity in ovarian follicular fluid. Fertil Streil 1985;44:219-23.

17. McClure N, Healy DL, Rogers PA, Sullivan J, Beaton L, Haning RV Jr, et al. Vascular endothelial growth factor as capillary permeability agent in ovarian hyperstimulation syndrome. Lancet 1994;344:235-6.

18. Guillaume $S$, Olufemi $O$, Anne D, Roger P, Gilbert V, Sabine C. Ovarian Hyperstimulation Syndrome Due to a Mutation in the Follicle-Stimulating Hormone Receptor. N Engl J Med 2003;349:760-6.

19. Pellicer A, Miro F, Sampaio M, Gomez E, Bonilla-Musoles FM. In vitro fertilization as a diagnostic and therapeutic tool in a patient with partial 17, 20-desmolase deficiency. Fertil Steril 1991;55:970-5.
20. Abramov Y, Schenker JG, Lewin A, Friedler S, Nisman B, Barak V Plasma inflammatory cytokines correlate to the ovarian hyperstimulation syndrome. Hum Reprod 1996;11:1381-6.

21. Rizk B, Aboulghar M, Smitz J, Ron-El $R$. The role of vascular endothelial growth factor and interleukins in the phatogenesis of severe ovarian hyperstimulation syndrome. Hum. Reprod. Updat 1997;3:255-66.

22. Gül A, Şimşek A. Overyan hiperstimülasyon sondromunun teşhisi, önlenmesi ve tedavisi. Dicle Tıp Dergisi (Journal of Medical School) 2000;27:4259.

23. Engel T, Jewelewicz R, Dyrenfurth I, Speroff L, Vande Wiele RL: Ovarian hyperstimulation syndrome: report of one case with notes on pathogenesis and treatment. Am J Obstet Gynecol 1972;112:1052-7.

24. Rabau E, David A, Serr DM, Mashiach S, Lunenfeld B. Human menopausal gonadotropins for anovulation and sterility. Results of 7 years of treatment. Am J Obstet Gynecol 1967;98:92-98.

25. Golan A, Ron-el R, Herman A, Soffer Y, Weinraub Z, Caspi E. Ovarian hyperstimulation syndrome: an update rewiev. Obstet Gynecol Surv 1989:44:430-40.

26. Kumar P, Sait SF, Sharma A, Kumar M. Ovarian J Hum Reprod Sci 2011;4:70-5.

27. Bellomo R, Ronco C, Kellum JA, Mehta RL, Palevski P. Acute Dialysis Quality Initiative workgroup. Acute renal failuredefinition, outcome measures, animal models, fluid therapy and information technology needs: the Second International Consensus Conference of the Acute Dialysis Quality Initiative (ADQI) Group. Crit Care 2004;8:204-12 
28. Marshall JC, Vincent JL, Fink MP, Cook DJ, Rubenfeld G, Foster D, et al. Measures, markers and mediators: toward astaging system for clinical sepsis. A report of the Fifth Toronto Sepsis Roundtable, Toronto, Ontario Canada, October 25-26 2000. Crit Care Med 2003;31:1560-7.

29. Bagshaw SM, Langenberg C, Haase M, Wan L, May CN, Bellomo R. Urinary biomarkers in septic acute kidney injury. Intensive Care Med 2007;33:1285-96.

30. Rivers E, Nguyen B, Hastad S, Ressler J, Muzzin A, Knoblich B, et al. Early goal-directed therapy in the treatment of severe sepsis and septic shock. N Engl J Med 2001;345:1368-77.

31. Dellinger RP, Levy MM, Carlet JM, Bion J, Parker MM, Jaeschke R, et al. Surviving Sepsis Campaing: international guidelines for management of severe sepsis and septic shock: 2008. Crit Care Med 2008;36:296-327.

32. Liu J, Ji B, Long C, LiS. Which is the optimal option during pediatric cardiopulmonary bypass: high colloid oncotic pressure priming, ultrafiltration or both? Eur J Cardiothorac Surg 2011;40:772.

33. Boldt J. Use of albumin: an update. Br J Anaesth 2010;104:276-84.

34. Cochrane Injuries Group. Human albumin administration in critically ill patients: systematic review of randomised controlled trials. Cochrane Injuries Group Albumin Reviewers. BJM 1998;317:23540.

35. SAFE Study Investigators; Australian and New Zealand Intensive Care Society Clinical Trials Group; Australian Red Cross Blood Service; George Institute for
International Health, Myburgh J, Cooper DJ, Finfer S, Bellomo R, Norton R, Bishop N, et al. Saline or albumin for fluid resuscitation in patients with traumatic brain injury. N Engl J Med 2007;357:87484.

36. O'Mara MS, Slater H, Goldfarb IW, Caushaj PF. A prospective, randomized evaluation of intra-abdominal pressures with crystalloid and colloid resuscitation in burn patients. J Trauma 2005;58:1011-8.

37. Oda J, Ueyama M, Yamashita K, Inoue T, Noborio M, Ode Y, et al. Hypertonic lactated saline resuscitation reduces the risk of abdominal compartment syndrome in severely burned patients. J Trauma 2006;60:64-71.

38. Abramov Y, Elchalal U, Schenker JG. An 'epidemic' of severe ovarian hyperstimulation syndrome: a price we have to pay? Hum. Reprod 1999;14:21813.

39. Levin MF, Kaplan BR, Hutton LC. Thoracic manifestations of ovarian hyperstimulation syndrome. Can Assoc Rad J 1995;46:23-6.

40. Yu H. Management of pleural effusion, empyema and lung abscess. Semin Intervent Radiol 2011;28:75-86

41. ARDS Definition Task Force, Ranieri VM, Rubenfeld GD, Thompson BT, Ferguson ND, Caldwell E, Fan E, Et al. Acute Respiratory Distress Syndrome The Berlin Definition. JAMA 2012;307:2526-33.

42. Stewart JA, Hamilton PJ, Murdoch AP. Thromboembolic disease associated with ovarian stimulation and assisted conception techniques. Human Reprod 1997;12:2167-73.
43. Andersen BS, Steffensen FH, Sorensen HT, Nielson GL, Olsen J. The cummulative incidence of venous thromboembolism during pregnancy and puerperium an 11 year Danish population based study of 63300 pregnancies. Acta Obstet Gynecol Scand 1998;77:110-3.

44. Biron C, Galtier - Dereuere F, Rabesandratana H, Bernard I, Aguilar Martinez P, Schved JF, et al. Hemostasis parameters during ovarian stimulation for invitro fertilization results of a prospective study. Fertil Steril Jan 1997;67:104-9.

45. Kim HC, Kemmann E, Shelden RM, Saidi P. Response of blood coagulation parameters to elevated endogenous 17 beta estradiol levels induced by human menapausal gonadotropins. Am J Obstet Gynecol 1981;140:807-10.

46. Rice VC, Richard Davis G, Saleh AA, Ginsburg KA, Mammen EF, Moghissi K, et al. Fibrinolytic parameters in women undergoing ovulation induction., Am J Obstet Gynecol Dec 1993;169:1549-53.

47. Aune B, Oian P,Osterud B. Enhanced sensitivity of the extrinsic coagulation system during ovarian stimulation for invitro fertilization. Hum Reprod Sep 1993;8:1349-52.

48. Curvers J, Nap AW, Thomassen MC, Nienhuis SJ, Hamulyak K, Evers JL, et al. Effect of in vitro ferilization treatment and subsequent pregnancy on the protein $\mathrm{C}$ pathway. Br J Haematol 2001;115:400-7.

49. Harrent MJ, Bhavani Shankar K, Data S, Tsen LC. In vitro fertilization induced alterations in coagulation and fibrinolysis as measured by thromboelastograpy. Anesth Analg 2002;95:1063-6. 